\title{
Pengaruh Financial Literacy dan Financial Behavior terhadap Keputusan Investasi pada Ibu-Ibu PKK Kota Jambi
}

\author{
Indah Mutiara ${ }^{1 *}$, Efandri Agustian ${ }^{2}$ \\ 1,2Program Studi S1 Akuntansi Universitas Adiwangsa Jambi \\ *Correspondence email: indahmutiara.akuntansi@gmail.com
}

\begin{abstract}
This study aims to determine the level of influence of Financial Literacy and Financial Behavior toward investment decisions. The data used in this study are primary data, the sample used in this study were PKK members in Jambi City. The sampling technique was carried out by using purposive sampling method. The results obtained by using multiple linear regression test $Y=2,337+0.159 X 1+0.518 X 2$, and the test of this study using the f-test, R2-test and t-test. The results of this study indicate that partially the Financial Literacy and Financial Behavior affect investment decisions.
\end{abstract}

Keywords: Financial Literacy, Financial Behavior and Investment

\section{Pendahuluan}

Krisis ekonomi global yang pernah terjadi telah memberikan dampak yang tidak pasti bagi perekonomian berbagai Negara termasuk Indonesia. Di masa krisis yang tengah menimpa dunia, Indonesia tetap stabil menjaga perkembangan perekonomiannya. Strategi keuangan yang dilakukan Indonesia adalah dengan mempercepat pertumbuhan ekonomi, lebih meratakan pertumbuhan itu dengan menyebarkan manfaatnya keseluruh lapisan masyarakat dalam memangkas kemiskinan. Salah satu jenis kegiatan yang berperan penting dalam pertumbuhan di bidang keuangan adalah kegiatan investasi baik itu secara luas seperti investasi dalam negeri ataupun luar negeri dan juga kegiatan investasi masyarakat negara itu sendiri. Dalam teori Harrod-Domar menyatakan bahwa agar tumbuh, perekonomian harus memiliki tabungan dan investasi dalam porsi tertentu terhadap Produk Nasional Bruto. Semakin banyak tabungan dan investasinya, semakin cepat perekonomian tersebut tumbuh. Selain itu dengan return atau keuntungan yang didapat ini maka akan tercapai tujuan pokok dari investasi yaitu maksimisasi kemakmuran dengan peningkatan kekayaan (Agustian, 2019).

Menurut Kiyosaki (2000), penyebab utama kemiskinan atau masalah finansial adalah ketakutan dan kebodohan atau ketidaktahuan, bukan soal ekonomi, pemerintah atau orang kaya. Banyak orang yang menjadi korban penipuan berkedok investasi karena tergiur dengan pengambalian yang tinggi dan kurangnya pengetahuan tentang keuangan. Dari Januari sampai April 2018 OJK telah menerima aduan penipuan berkedok investasi bodong sebanyak 72 kasus. Oleh karena itu literasi keuangan sangat penting untuk menunjang pengetahuan masyarakat mengenai produk-produk investasi dan manajemen keuangan pribadi. Kecerdasan finansial di era modern saat ini mutlak diperlukan oleh masyarakat. Hal ini, dikarenakan kecerdasan finansial yang meliputi bagaimana seseorang mengelola finansial yang dimiliki dengan baik adalah modal untuk memperbaiki kesejahteraan masing-masing individu. Seringkali kegagalan seseorang dalam mengelola keuangan bukan disebabkan karena rendahnya pendapatan seseorang, tetapi lebih pada faktor ketidaktahuan individu dalam mengalokasikan pendapatan pada pos-pos tertentu. Kecerdasan finansial yang baik ditandai dengan adanya pemahaman literasi keuangan (financial literacy) yang tinggi.

Dalam melakukan keputusan investasi, memilih merupakan pekerjaan yang tidak mudah bagi investor terutama dalam situasi ketidakpastian yang tinggi. Dalam pengambilan keputusan, pendekatan keuangan konvensional menggunakan dua asumsi, yaitu individu akan membuat keputusan yang rasional dan tidak mengalami bias akan prediksi tentang masa depan (Nofsinger, 2005). Akan tetapi dalam prakteknya, asumsi bahwa individu akan berperilaku rasional tidak sepenuhnya terjadi karena adanya keterbatasan kemampuan berpikir dan menjadi alasan munculnya ilmu keuangan berbasis perilaku (Behavioral finance). Target Otoritas Jasa Keuangan (OJK) agar terciptanya masyarakat yang melek keuangan adalah pada Ibu Rumah Tangga, UMKM, Profesional, Pelajar, Mahasiswa Karyawan dan Pensiunan. Perencanaan investasi bagi Ibu-ibu sangatlah perlu, karena dari Ibu-ibu berawal segala macam bentuk keuangan rumah tangga itu di proses. Tujuan penelitian ini adalah untuk mengetahui pengaruh Financial Literacy dan Financial Behavior terhadap keputusan investasi pada Ibu-Ibu PKK Kota Jambi Kota Jambi.

\section{Landasan Teori \\ Investasi}

Ary (2011) megatakan bahwa investasi adalah kegiatan yang dimaksudkan untuk menunda konsumsi hari ini untuk di konsumsi pada waktu mendatang, dengan harapan nilai di waktu mendatang lebih tinggi daripada nilai yang ditemui hari ini. Untuk melakukan keputusan investasi, investor memerlukan informasi-informasi yang merupakan faktor-faktor penting sebagai dasar untuk menentukan pilihan investasi. Dari informasi yang ada, kemudian 
membentuk suatu model pengambilan keputusan yang berupa kriteria penilaian investasi untuk memungkinkan investor memilih investasi terbaik di antara alternatif investasi yang tersedia.

Dalam konteks keputusan investasi, Manurung (2012) mengatakan bahwa seorang pengambil keputusan yang menerima umpan balik negatif atas keputusan investasi sebelumnya akan berada pada posisi atau kondisi rugi, dan akan memandang keputusan berikutnya sebagai pilihan antara kerugian pasti yang telah terjadi (yaitu memilih untuk tidak melanjutkan tindakan menambah investasi) dengan kerugian di masa mendatang yang kurang pasti (yaitu mengambil risiko menambah dana dengan harapan mendapat pengembalian positif). Dalam keadaan ini, pengambil keputusan cenderung untuk mencari risiko, memilihkerugian yang tidak pasti yang memberikan harapan perbaikan (komitmen tambahan dana) dibandingkan kerugian yang pasti. Salah satu contoh yang cukup menarik dilihat adanya rasional terikat (bounded rationality) dalam berinvestasi. Pada sisi lain terjadi juga investor menjual secepatnya saham yangdimiliki bila kelihatan sudah untungl dan menahan saham sangat lama ketika harga saham turun (Shefrin, 2005). Kasus ini memperlihatkan investor tidak mau mengalami kerugian atas investasi yang dimilikinya. Saham yang sudah drop tidak dijual sampai saham tersebut naik kembali sampai mendapatkan untung sedikit baru dijualnya. Keputusan investasi adalah bersifat individual dan tergantung sepenuhnya kepada pribadi yang bebas (Rusdin, 2006). Sebelum melakukan kegiatan investasi para investor juga harus dapat mempertimbangkan keuntungan dan risiko yang akan diperoleh di masa yang akan datang. Dasar keputusan investasi (Tandelilin, 2013) adalah:

a. Return (tingkat pengembalian), alasan berinvestasi adalah untuk memperoleh keuntungan. Dalam manajemen investasi tingkat keuntungan investasi disebut sebagai return. Return yang diharapkan investor dari investasi yang dilakukannya merupakan kompensasi atas biaya kesempatan (opportunity cost) dan resiko penurunan daya beli akibat adanya pengaruh inflasi.

b. Risk (risiko), korelasi langsung antara pengembalian dengan risiko, yaitu semakin tinggi pengembalian, semakin tinggi risiko. Oleh karena itu, investor harus menjaga tingkat risiko dengan pengembalian yang seimbang.

c. The Time Factor (waktu), jangka waktu adalah hal penting dari definisi investasi. Investor dapat menanamkan modalnya pada jangka pendek, jangka menengah atau jangka panjang. Pemilihan jangka waktu investasi sebenarnya merupakan suatu hal penting yang menunjukkan ekspektasi atau harapan dari investor.

\section{Literacy Financial}

Menurut Otoritas Jasa Keuangan (OJK) literasi keuangan (Financial Literacy) didefinisikan sebagai tingkat pengetahuan, keteramilan, keyakinan masyarakat terkait lembaga keuangan serta produk dan jasanya yang dituangkan dalam parameter ukuran indeks. Yulianti (2013) berpendapat bahwa pengetahuan keuangan merupakan segala sesuatu tentang keuangan yang dialami atau yang terjadi dalam kehidupan sehari-hari. Pengetahuan keuangan juga dapat didefinisikan sebagai penguasaan seseorang atas berbagai hal tentang dunia keuangan, yang terdiri dari alat keuangan dan keterampilan keuangan (Andrew, 2014). Keterampilan keuangan (financial skill) sebagai sebuah teknik untuk membuat keputusan dalam manajemen keuangan pribadi (Ida, 2010). Menyiapkan sebuah anggaran, memilih investasi, memilih rencana asuransi, dan menggunakan kredit adalah contoh dari keterampilan keuangan (financial skill). Literasi keuangan dapat diartikan sebagai pengetahuan keuangan dengan tujuan mencapai kesejahteraan (Lusardi, 2014). Untuk mencapai kesejahteraan tersebut masyarakat harus mengetahui bagaimana cara mencapai kesejahteraan mulai dari perencanaan sampai penggunaan, hal ini mengacu pada kondisi keuangan masyarakt. Dengan berapapun pengasilan masyarakat jika masyarakat mampu mengalokasikan keuangannya pada lembaga yang benar maka tidak akan terjadi risiko keuangan melainkan keuntungan dan kesejahteraanpun akan tercapai. Salah satu risiko keuangan adalah penggunaan dana yang tidak sesuai kebutuhan, hilangnya dana baik disengaja maupun tidak disengaja. Dalam rangka mencapai kemerdekaan keuangan, pengetahuan dan implementasi atas praktik keuangan pribadi yang sehat, idealnya perlu dipunyai dan dilakukan oleh setiap orang (Warsono. 2010). Sejauh mana pengetahuan dan implementasi seseorang atau masyarakat dalam mengelola keuangan pribadinya ini sering dikenal sebagai literasi (kemelekan) keuangan (financial literacy).

Saat ini gerakan sadar keuangan/Financial Literacy di Indonesia sangat didukung oleh pemerintah. Meningkatkan literasi keuangan bagi masyarakat indonesia merupakan strategi nasional yang diamanatkan kepada Otoritas Jasa Keuangan (OJK). Pengetahuan keuangan telah terbukti memiliki dampak yang signifikan terhadap manajemen keuangan, dan lebih konsisten ketika berbagai macam kebijakan digunakan (Sarah, 2009). Hal ini dapat dijelaskan melalui cara seseorang mengelola keuangan pribadinya dan manajemen keuangan itu menjadi faktor utama yang berkontribusi terhadap kepuasan keuangan atau ketidakpuasan keuangan seseorang. Secara teoritis menurut Robb (2011), pengetahuan keuangan tentang bagaimana pasar keuangan beroperasi harus menghasilkan individu yang membuat keputusan lebih efektif. Sedangkan Hilgert etal, (2003) berpendapat bahwa seseorang yang memiliki pengetahuan keuangan lebih cenderung berperilaku keuangan dengan cara-cara yang bertanggung jawab secara keuangan. Penelitian Hilgert tersebut menunjukkan bahwa pengetahuan keuangan dan perilaku keuangan berpengaruh positif. Hasil penelitian ini didukung oleh teori perilaku keuangan yang mengguakan proses kognitif (keterampilan mental manusia dalam memahami dan mengenali hal-hal sekitar) dalam manajemen dan pemecahan masalah dalam 
pengambilan keputusan.

\section{Financial Behavior}

Keputusan investasi ini didasarkan pada dua hal yaitu portofolio dan profitabilitas (keuntungan). Portofolio itu sendiri merupakan pembelian saham dengan momentum harga pada saat yang sama mengabaikan prinsip supply and demand yang sebenarnya sudah diketahui dalam financial behavior sebagai herd behavior (perilaku serentak). Financial Behavior adalah suatu perilaku yang berkaitan dengan aplikasi keuangan. Financial behavior adalah suatu displin ilmu yang di dalamnya melekat interaksi berbagai displin ilmu dan secara terus menerus berintegrasi sehingga pembahasannya tidak dilakukan isolasi (Ricciardi, 2000). Seseorang yang ingin mempelajari perilaku keuangan harus memiliki pengertian mengenai aspek psikologi, sosiologi, dan keuangan. Financial behavior adalah studi yang mempelajari bagaimana fenomena psikologi mempengaruhi tingkah laku keuangannya (Shefrin, 2005). Perilaku keuangan yaitu mempelajari bagaimana manusia secara actual berperilaku dalam sebuah penentuan keuangan (financial setting).

Sedangkan menurut Olseon (2014) memberikan perspektif perilaku keuangan dari proses pengambilan keputusan sebagai berikut:

- Preferensi pengambil keputusan Keuangan 'cenderung multifaceted, terbuka untuk perubahan dan sering terbentuk selama proses pengambilan keputusan itu sendiri.

- Pengambil keputusan keuangan adalah satisficers dan tidak pengoptimalan.

- Pengambil keputusan keuangan yang adaptif berarti bahwa sifat keputusan dan lingkungan dimana itu membuat pengaruh jenis proses yang digunakan

- Pengambil keputusan keuangan secara neurologis cenderung untuk menggabungkan mempengaruhi (emosi) ke dalam proses pengambilan keputusan.

- Perilaku keuangan itu sendiri juga berasal dari ekonomi neoklasik, Homo economicus adalah model perilaku ekonomi manusia yang sederhana mengasumsikan bahwa prinsip-prinsip kepentingan pribadi sempurna, rasionalitas yang sempurna, dan informasi yang sempurna mengatur keputusan ekonomi individu (Michael M. Pompian, 2006).

\section{Hipotesis}

Hipotesis yang diajukan adalah :

H1 : Financial Literacy dan Financial Behavior secara bersama-sama berpengaruh signifikan terhadap pilihan Keputusan Investasi.

H1a : Financial Literacy berpengaruh signifikan terhadap pilihan Keputusan Investasi.

$\mathrm{H1b}$ :Financial Behavior berpengaruh signifikan terhadap pilihan Keputusan Investasi.

\section{Metode}

Berdasarkan jenis penelitian maka jenis penelitian ini tergolong sebagai penelitian kuantitatif yang menguji hipotesis. Berdasarkan tujuan studi maka penelitian ini tergolong penelitian korelasional. Penelitian ini lebih terfokus pada penggunaan kuesioner. Penelitian ini dilakukan pada Ibu-ibu PKK Kota Jambi. Waktu yang diperlukan untuk penelitian ini adalah yaitu mulai dari bulan Agustus 2020 sampai selesai.

\section{Hasil \\ Hasil Uji Validitas}

Tabel 1

Ringkasan Uji Validitas

\begin{tabular}{ccccc}
\hline Variabel & Item & r hitung & r tabel & Keterangan \\
\hline X1.1 & 0.859 & 0.361 & Valid \\
X1.2 & 0.714 & 0.361 & Valid \\
X1.3 & 0.493 & 0.361 & Valid \\
& X1.4 & 0.884 & 0.361 & Valid \\
& X1.5 & 0.772 & 0.361 & Valid \\
& X1.6 & 0.857 & 0.361 & Valid \\
& X1.7 & 0.935 & 0.361 & Valid \\
& X1.8 & 0.806 & 0.361 & Valid \\
X1.9 & 0.757 & 0.361 & Valid \\
& X1.10 & 0.836 & 0.361 & Valid \\
& X1.11 & 0.859 & 0.361 & Valid \\
& X1.12 & 0.714 & 0.361 & Valid
\end{tabular}


Indah Mutiara dan Efandri Agustian, Pengaruh Financial Literacy dan Financial Behavior terhadap Keputusan Investasi pada Ibu-Ibu PKK Kota Jambi

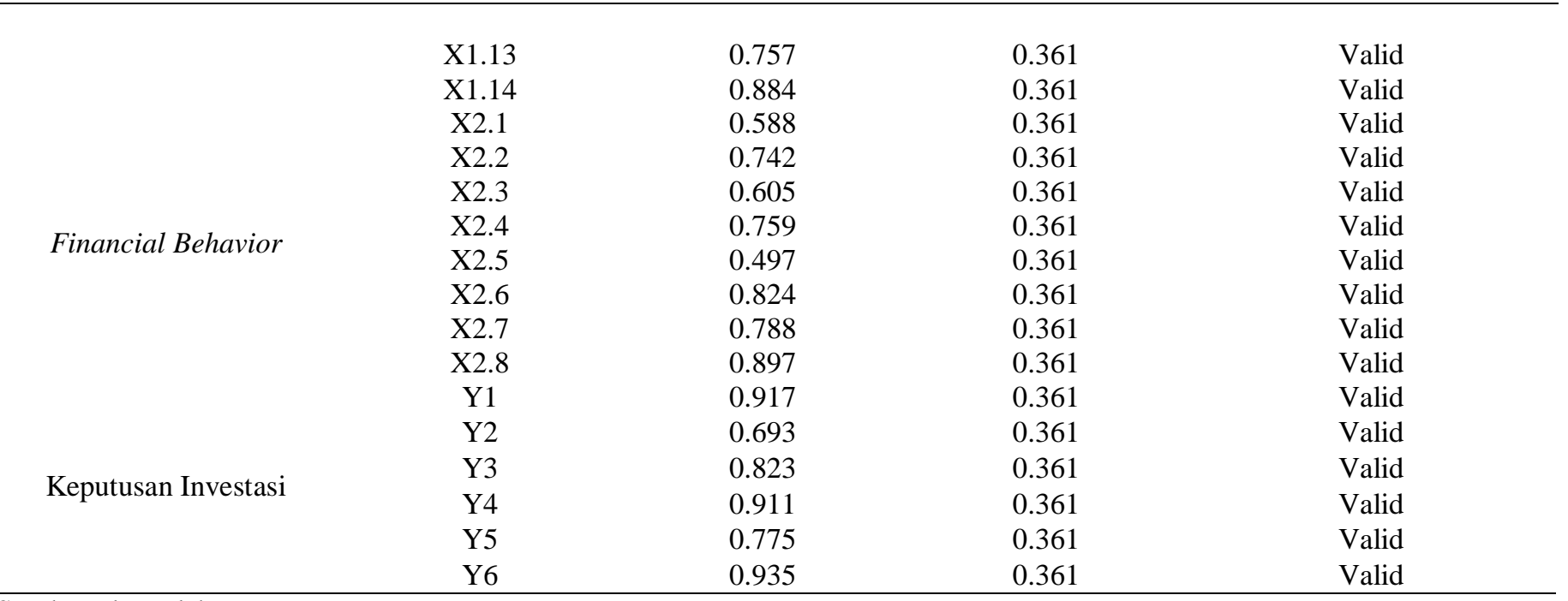

Sumber: data olahan

\section{Uji Reliabilitas}

Uji reliabilitas digunakan untuk menilai konsistensi dari instrumen penelitian dapat dikatakan reliabel jika nilai cronbach alpha > 0,60 (Ghozali, 2014) untuk hasil uji reliabilitas dalam penelitian ini dapat dilihat dari tabel berikut.

Tabel 2

Reliability Statistics

\begin{tabular}{|c|c|c|}
\hline Cronbach's Alpha & Cronbach's Alpha Based on Standardized Items & $\mathrm{N}$ of Items \\
\hline 0.773 & 0.962 & 15 \\
\hline
\end{tabular}

Sumber: data olahan

Tabel 3

Reliability Statistics

\begin{tabular}{|r|r|r|r|}
\hline \multicolumn{2}{|r|}{ Cronbach's Alpha } & Cronbach's Alpha Based on Standardized Items & N of Items \\
\hline & 0.774 & 0.900 & 9 \\
\hline
\end{tabular}

Sumber: data olahan

\section{Tabel 4}

Reliability Statistics

\begin{tabular}{|c|c|c|}
\hline Cronbach's Alpha & Cronbach's Alpha Based on Standardized Items & $\mathrm{N}$ of Items \\
\hline 0.807 & 0.944 & 7 \\
\hline
\end{tabular}

Sumber: data olahan

\section{Uji Multikolinieritas}

Tabel 5

Coeffisiens

\begin{tabular}{|rlr|r|r|r|r|}
\hline \multicolumn{2}{|c|}{ Model } & \multicolumn{2}{c|}{$\begin{array}{c}\text { Unstandardized Coefficients } \\
\text { Std. Error }\end{array}$} & $\begin{array}{c}\text { Standardized Coefficients } \\
\text { Beta }\end{array}$ & \multicolumn{2}{c|}{$\begin{array}{c}\text { Collinearity Statistics } \\
\text { Tolerance }\end{array}$} \\
\hline \multirow{2}{*}{ 1 } & (Constant) & 2.337 & 1.738 & & & \\
& SUM_X1 & 0.159 & 0.066 & 0.333 & 0.445 & 2.247 \\
& SUM_X2 & 0.518 & 0.119 & 0.601 & 0.445 & 2.247 \\
\hline
\end{tabular}

Sumber: data olahan

\section{Hasil Uji Koefisien Adjusted R Square $\left(\boldsymbol{R}^{2}\right)$}

Tabel 6

Model Summary

\begin{tabular}{|c|r|r|r|r|}
\hline Model & R & R Square & Adjusted R Square & \multicolumn{1}{c|}{ Std. Error of the Estimate } \\
\hline 1 & $.877^{\mathrm{a}}$ & 0.770 & 0.753 & 2.01784 \\
\hline
\end{tabular}

Sumber: data olahan 
Indah Mutiara dan Efandri Agustian, Pengaruh Financial Literacy dan Financial Behavior terhadap Keputusan Investasi pada Ibu-Ibu PKK Kota Jambi

Uji Simultan (Uji F)

\begin{tabular}{|c|c|c|c|c|c|c|}
\hline \multicolumn{7}{|c|}{$\begin{array}{c}\text { Tabel } 7 \\
\text { ANOVA }^{\mathrm{a}}\end{array}$} \\
\hline & Model & Sum of Squares & $\mathrm{df}$ & Mean Square & $\mathrm{F}$ & Sig. \\
\hline 1 & $\begin{array}{l}\text { Regression } \\
\text { Residual } \\
\text { Total }\end{array}$ & $\begin{array}{l}367.353 \\
109.935 \\
477.288\end{array}$ & $\begin{array}{c}2 \\
27 \\
29\end{array}$ & $\begin{array}{c}183.677 \\
4.072\end{array}$ & 45.111 & $.000^{\mathrm{b}}$ \\
\hline
\end{tabular}

Sumber: data olahan

\section{Hasil Uji $t$}

Tabel 8

Coefficients ${ }^{\mathrm{a}}$

\begin{tabular}{|c|c|c|c|c|c|c|}
\hline \multirow{2}{*}{\multicolumn{2}{|c|}{ Model }} & \multicolumn{2}{|c|}{ Unstandardized Coefficients } & \multirow{2}{*}{$\frac{\text { Standardized Coefficients }}{\text { Beta }}$} & \multirow{2}{*}{$\mathrm{t}$} & \multirow{2}{*}{ Sig. } \\
\hline & & B & Std. Error & & & \\
\hline 1 & $\begin{array}{l}\text { (Constant) } \\
\text { Financial_Literacy } \\
\text { Financial_Behavior }\end{array}$ & $\begin{array}{l}2.337 \\
0.159 \\
0.518\end{array}$ & $\begin{array}{l}1.738 \\
0.066 \\
0.119\end{array}$ & $\begin{array}{l}0.333 \\
0.601\end{array}$ & $\begin{array}{l}1.345 \\
2.403 \\
4.340\end{array}$ & $\begin{array}{l}0.190 \\
0.023 \\
0.000\end{array}$ \\
\hline
\end{tabular}

Sumber: data olahan

\section{Simpulan}

Berdasarkan hasil pengujian yang dilakukan terhadap 30 responden Ibu-ibu PKK Kota Jambi diperoleh hasil sebagai berikut:

1. Dari pengujian secara simultan atau bersama-sama dapat diketahui bahwa $F$ hitung sebesar 45.111 dengan nilai signifikansi sebesar $0,000<\alpha(5 \%)$, maka H1 diterima dan H0 ditolak. Sehingga dapat di simpulkan variabel Financial Literacy (X1) dan Financial Behavior (X2) secara simultan berpengaruh signifikan terhadap Keputusan investasi (Y).

2. Variabel Financial Literacy (X1) diperoleh nilai t hitung sebesar 2,403 dengan nilai signifikansi sebesar $0,023<\alpha$ (5\%), maka H1 diterima dan H0 ditolak Maka disimpulkan bahwa secara parsial Variabel Financial Literacy (X1) berpengaruh positif terhadap pilihan Keputusan investasi (Y).

3. Variabel Financial Behavior (X2) diperoleh nilai t hitung sebesar 4,340 dengan nilai signifikansi sebesar $0,000<\alpha$ (5\%), maka H1 diterima dan H0 ditolak. Maka disimpulkan bahwa secara parsial Variabel Financial Behavior (X2) berpengaruh positif terhadap pilihan Keputusan investasi (Y).

\section{Daftar Pustaka}

Agustian, Efandri. 2019. Reaksi Pasar Modal Terhadap Aksi Unjuk Rasa Bela Islam Jilid I, Jilid II \& Jilid III (Studi Kasus: Perusahaan Yang Tergabung Dalam Indeks LQ-45). Jurnal Manajemen Jambi. Universitas Adiwangsa Jambi: 2(1), 96-102.

Aminatuzzahra, 2014. Persepsi Pengaruh Pengetahuan Keuangan, Sikap Keuangan, Sosial Demografi Terhadap Perilaku Keuangan Dalam Pengambilan Keputusan Investasi Individu. Jurnal Bisnis Strategi. 23(2).

Andrew, Vincentius dan Linawati, Nanik. 2014. Hubungan Faktor Demografi dan Pengentahuan Keuangan dengan Perilaku Keuangan Karyawan di Surabaya. Finesta, 2(2)

Ary, Tatang Gumanti. 2011. Manajemen Investasi: Konsep, Teori dan Aplikasi. Jakarta.: Mitra Wacana Media

Ghozali, 2014. Aplikasi analisis Multivariate dengan Program SPSS. Badan Penerbit. UNDIP, Semarang.

Hilgert, Marianne A., Jeanne M. Holgarth, Sondra Beverly. 2003. Household Financial Management: The Connection between Knowledge and Behavior. Federal Reserve Bulletin

Ida dan Dwinta CY. 2010. Pengaruh Locus of Control, Financial Knowledge, Income Terhadap Financial Management Behavior. Jurnal Bisnis dan Akuntansi. 12(3).

Kiyosaki, Robert. 2000. Cashflow Quadrant. Jakarta: Gramedia Pustaka Utama.

Lusardi, A., \& Mithcell, O. S. 2014. The Economic Importance of Financial Literacy: Theory and Evidence. Journal of Economic Literature, 52(1), 5-44.

Manurung, Adler Haymar. 2012. Teori Prilaku Keuangan. PT. Adler Manurung Press.

Michael M. Pompian, 2006. Behavioral Finance and Wealth Management. (New Jersey, Canada: John Wiley \& Sons, Inc., Hoboken).

Nofsinger, Jhon R. 2005. Psychologi of Investing. Second Edition. New Jersey. Precentice-Hall Inc.

Ricciardi, V dan Simon, H.K. 2000. What is Behavioral Finance?. Business Educational and Techonology Journal Fall 2000. 
Indah Mutiara dan Efandri Agustian, Pengaruh Financial Literacy dan Financial Behavior terhadap Keputusan Investasi pada Ibu-Ibu PKK Kota Jambi

Robb, C. A., \& Woodyard, A. S. 2011. finanacial knowledge and best practice behaviour. Journal of financial Counseling and planning, 22(1).

Rusdin. 2006. Pasar Modal: Teori, Masalah dan Kebijakan Dalam Praktik. Bandung: Alfabeta.

Sarah, N. 2009. Financial Knowledge, Locus Of Control, Cultural Values And Financial Behaviour Among New Vision. A Dessertation Submitted In Partial Fulilment Of The Reaquirements For The Award Of The Degree Of Master Of Makerere University Kampala, 54.

Shefrin, Hers. 2005. Understanding Behavioral Capital Asset Pricing theory. Journal of Financial and Quantitative Analysis.

Tandelilin, Eduardus. 2013. Portofolio dan Investasi Teori dan Aplikasi. Yogyakarta: Kanisius.

Vyas, Ravi. 2012, Mutual Fund Investor's Behaviour And Perception In Indore City. Researchers World, 3(3), 67-75

Warsono. 2010. Prinsip-prinsip dan Praktik Keuangan Pribadi. Journal of Science. 13(2)

Yohnson. 2008. Regret Aversion dan Risk Tolerance Investor Muda Jakarta dan Surabaya. Jurnal Manajemen dan Kewirausahaan, 10(2), 163-168.

Yulianti, Norma dan Silvy Meliza. 2013. Sikap Pengelola Keuangan dan Perilaku Perencanaan Investasi Keluarga di Surabaya. Journal of Business and Banking 3(1) 